\title{
APLIKASI TEST POTENSI AKADEMIK SELEKSI SARINGAN MASUK LP3I BERBASIS WEB ONLINE MENGGUNAKAN FRAMEWORK CODEIGNITER
}

\author{
Ahmad Sahi \\ Politeknik LP3I \\ email: ahmadsahi@plb.ac.id
}

\begin{abstract}
Abstrak : Aplikasi Test potensi akademik seleksi saringan masuk LP3I berbasis web online menggunakan Framework Codeigniter. Masalah yang terjadi test masuk masih adanya pelaksanaan test masuk seleksi mahasiswa masih menggunakan secara manual sehingga proses hasil testnya masih perlu butuh waktu untuk mengetahui hasil dari test tersebut, dengan adanya aplikasi secara online ini secara menyeluruh memudahkan untuk pengambilan keputusan dan mengetahu hasil lebih cepat, serta mengetahui calon mahasiswa tersebut apakah diterima atau tidak. Dengan adanya aplikasi online ini calon mahasiswa dapat mengakses dimana saja dan dapat test dimana saja dengan kondisi Covid19 ini dituntut untuk serba online dan digital karena belum memungkinkan untuk bisa datang ke kampus. Aplikasi yang dirancang merupakan berbasis web online yang dibuat menggunakan Framework CodeIgniter dipastikan akan membantu departemen tertentu untuk lebih cepat mengetahui hasil dari calon mahasiswa yang mengikuti test tersebut. Aplikasi ini berfungsi untuk membantu pelaksanaan tes secara online yang dgunakan langsung oleh peserta tes (user). Aplikasi ini memunculkan soal-soal beserta pilihan jawaban yang diambil dari database yang sudah diatur oleh administrator. Cakupan produk aplikasi yang dibuat adalah sistem pengambil keputusan dan sistem penilaian, sistem ini tidak melayani masalah administrasi yang berlaku untuk mengikuti tes, aplikasi ini hanya membantu penyelenggara dalam menyelenggarakan tes.Karakteristik User berikut deskripsi user account di dalam penggunaan aplikasi: User, merupakan peserta tes atau ujian yang sudah terdaftar. User dapat melakukan login, mengikuti tes, dan melihat hasil akhir dari tes. Administrator, merupakan pengatur atau penyelenggara tes. Administrator dapat melakukan login, mendaftarkan user, mengelola user, dan mengelola soal tes. Metode yang digunakan penulis dalam penelitian ini adalah dengan metode deskriptif. Sedangkan metode yang digunakan penulis dalam pengumpulan data meliputi observasi partisipan, studi pustaka dan wawancara. Dengan dibuatkannya Aplikasi Test potensi akademik seleksi saringan masuk LP3I berbasis web online menggunakan Framework Codeigniter menjadi efektif, efisien, akurat dan lebih baik.
\end{abstract}

Kata Kunci : Aplikasi, Test online, Framework, Codeigniter

\section{Pendahuluan}

Kemajuan teknologi di era digital ini dan situasi yang dituntuk serba cepat dan bisa diakses dari mana saja dan kita dituntut untuk selalu mengikuti perkembangannya, tidak sedikit dari institusi atau lembaga pendidikan yang memanfaatkan dari perkembangan teknologi informasi ini, teknologi informasi sudah dijadikan bagian yang penting dari proses pekerjaan, karena kecepatan, kemudahan dan keakuratannya sangat membantu dalam proses penyelesaian pekerjaan, dimana instansi atau perusahaan dituntut untuk menyelesaikan setiap pekerjaannya dengan cepat dan akurat. 
Tes Potensi Akademik merupakan tes psikologi yang digunakan untuk mengukur tingkat scholastic seseorang. Tes Potensi Akademik sering digunakan dalam penyeleksian mahasiswa baru dan penyeleksian karyawan atau pegawai baru, bahkan untuk penyeleksian pimpinan suatu institusi negeri atau swasta. Dalam pelaksanaannya, masih sering menggunakan media kertas, untuk mengurangi penggunaan kertas, maka diperlukan sebuah aplikasi komputer yang dapat menangani pelaksanaan tes.

Aplikasi yang dirancang merupakan aplikasi tes berbasis web online yang dibuat menggunakan framework CodeIgniter. Penggunaan aplikasi ini ditujukan khusus untuk pelaksanaan Tes Potensi Akademik yang mudah digunakan dan lebih efisien dibanding dengan tes tertulis yang menggunakan kertas.

\section{Landasan Teori}

\subsection{Pengertian PHP (Hypertext Preprocessor)}

PHP merupakan singkatan dari PHP Hypertext Preprocessor yang digunakan sebagai bahasa script server-side dalam pengembangan web yang disisipkan pada dokumen HTML. PHP merupakan software open source yang disebarkan dan dilisensikan secara gratis serta dapat didownload secara bebas dari situs resminya http://www.php.net.

Kelebihan dari PHP, yaitu :

a. Bahasa pemoraman PHP adalah sebuah bahasa script yang tidak melakukan sebuah kompilasi dalam penggunanya.

b. Web server yang mendukung PHP dapat ditemukan dimana-mana dari mulai

apache, IIS, Lightpd, nginx, hingga Xitami dengan konfigurasi lebih mudah.

c. Dalam sisi pengembangan lebih mudah, karena banyaknya milis-milis dan developer yang siap membantu pengembangan.

d. Dalam sisi pemahaman, PHP adalah bahasa scripting yang paling mudah karena memiliki referensi yang banyak.

e. PHP adalah bahasa open source yang dapat digunakan dibeberapa mesin (Linux, Unix, Macintosh, Windows) dan dapat dijalankan secara runtime melalui console serta juga dapat menjalankan perintah-perintah system.

\subsection{Pengertian MySQL}

Menurut David M. Kroenke (2005 : 220) MySQL adalah produk DBMS open sorce yang berjalan pada UNIX, Linux, dan Windows. Sumber dan kode biner MySQL dapat didownload dari situs Web MySQL (http://www.mysql.com). Keterbatasan MySQL tidak mendukung View, prosedur tersimpan, maupun trigger. Akan tetapi, semua hal tersebut ada pada to-do-list MySQL, sehingga periksa dokumentasi terakhir untuk menentukan apakah beberapa fitur-fitur tersebut telah ditambahkan ke produk tersebut pada realese-realese yang terbaru.

\subsection{Pengertian PHP Storm 2.0}

PhpStorm adalah PHP IDE ringan dan cerdas berfokus pada produktivitas pengembang yang sangat memahami kode Anda, menyediakan penyelesaian kode cerdas, navigasi cepat dan memeriksa on-the-fly kesalahan. Itu selalu siap untuk membantu Anda membentuk kode Anda, menjalankan unit-tes atau memberikan debugging visual. PhpStorm mencakup semua fungsi WebStorm 
(HTML / CSS Editor, Javascript Editor) dan menambahkan dukungan penuh untuk PHP. http://www.jetbrains.com/phpstorm/

\subsection{Pengertian JavaScript}

Javascript diperkenalkan pertama kali oleh Netscape pada tahun 1995. Pada awalnya bahasa ini dinamakan "LiveScript" yang berfungsi sebagai bahasa sederhana untuk browser Netscape Navigator 2. Javascript adalah bahasa yang berbentuk kumpulan skrip yang pada fungsinya berjalan pada suatu dokumen HTML, sepanjang sejarah internet bahasa ini adalah bahasa skrip pertama untuk web. Bahasa ini adalah bahasa pemrograman untuk memberikan kemampuan tambahan terhadap bahasa HTML dengan mengijinkan pengeksekusian perintah perintah di sisi user, yang artinya di sisi browser bukan di sisi server web. Javascript bergantung kepada browser (navigator) yang memanggil halaman web yang berisi skrip-skrip dari Javascript dan tentu saja terselip di dalam dokumen HTML.

\subsection{Pengertian Jquery}

JQuery merupakan suatu framework (library) Javascript yang menekankan bagaimana interaksi antara Javascript dan HTML. JQuery pertama kali dirilis pada tahun 2006 oleh John Resig. Fitur utama dari JQuery diantaranya :

a. Dapat mengakses elemen dalam dokumen

Javascript khusus, untuk mengakses suatu bagian tertentu dari halaman, harus mengikuti aturan Document Object Model dan pengaksesan harus secara spesifik menyesuaikan dengan struktur HTML.

b. Mengubah tampilan halaman website CSS (Cascading Style Sheet) menawarkan metode yang cukup handal dalam mengatur dan mempercantik halaman web.

c. Mengubah isi dari dokumen

Tidak hanya memberikan "kosmetik" pada halaman web, JQuery juga memberikan fasilitas untuk mengubah isi dari dokumen hanya dengan beberapa baris perintah.

d. Merespon interaksi user

Javascript sendiri memiliki beberapa event-handling seperti onclick untuk menangani event saat terjadi click.

e. Animasi pada dokumen

Animasi seringkali disertakan dalam suatu halaman web untuk menambah kecantikannya.

f. Mengambil informasi dari server tanpa harus me-refresh halaman

Mengambil informasi dari server tanpa refresh halaman merupakan salah satu konsep dasar yang dikenal dengan nama AJAX (Asynchronous Javascript and XML).

g. Menyederhanakan penulisan sintaks Javascript

Semboyan JQuery adalah "Write less, do more" atau dengan kata lain kesederhanaan dalam penulisan code, tetapi menghasilnya tampilan yang lebih.

\subsection{Pengertian Basis Data}

Menurut Connoly dan Begg (2002 : 14), pengertian basis data yaitu kumpulan koleksi data-data yang saling berhubungan secara logika yang isinya didesain untuk memenuhi kebutuhan informasi dari suatu perusahaan. 
Ada beberapa istilah umum yang sering dipakai pada database, yaitu sebagai berikut :

a. Field, yaitu sekumpulan kecil dari kata atau sebuah deretan angka-angka.

b. Record, yaitu kumpulan dari field yang berelasi secara logis.

c. File, yaitu kumpulan dari record yang berelasi secara logis.

d. Entity, yaitu orang, tempat, benda, atau kejadian yang berkaitan dengan informasi yang disimpan.

e. Attribute, yaitu setiap karakteristik yang menjelaskan suatu entity.

f. Primary key, yaitu sebuah field yang nilainya unik yang tidak sama antara satu record dengan record yang lain.

g. Foreign key, yaitu sebuah field yang nilainya berguna untuk menghubungkan primary key yang berada pada table yang berbeda.

\subsection{Pengertian CodeIgniter}

Menurut Hakim (2010:8) CodeIgniter adalah sebuah framework PHP yang dapat membantu mempercepat developer dalam pengembangan aplikasi web berbasis PHP dibanding jika menulis semua kode program dari awal.

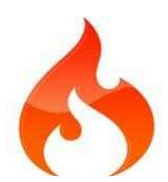

Gambar 1. Logo CodeIgniter

CodeIgniter pertama kali dibuat oleh Rick Ellis, CEO Ellislab, Inc. (http://ellislab.com), sebuah perusahaan yang memproduksi CMS (Content Management System) yang cukup handal,yaitu Expression Engine (http://www.expressionengine.com). Saat ini, CodeIgniter dikembangkan dan dimaintain oleh Expression Engine Development Team.

Adapun beberapa keuntungan menggunakan CodeIgniter, diantaranya:

a. Gratis

CodeIgniter berlisensi dibawah Apache/BSD opensorce.

b. Ditulis Menggunakan PHP 4

Meskipun CodeIgniter dapat berjalan di PHP 5, namun sampai saat ini kode program CodeIgniter masih dibuat dengan menggunakan PHP 4.

c. Berukuran Kecil

Ukuran CodeIgniter yang kecil merupakan keunggulan tersendiri. Dibanding dengan framework lain yang berukuran besar.

d. Menggunakan Konsep MVC

CodeIgniter menggunakan konsep MVC yang memungkinkan pemisahan layer application-logic dan presentation

e. URL yang Sederhana

Secara default, URL yang dihasilkan CodeIgniter sangat bersih dan Serach Engine Friendly (SEF).

f. Memiliki Paket Library yang Lengkap

CodeIgniter mempunyai library yang lengkap untuk mengerjakan operasioperasi yang umum dibutuhkan oleh sebuah aplikasi berbasis web, misalnya mengakses database, mengirim email, memvalidasi form, menangani session dan sebagainya.

g. Extensible 
Sistem dapat dikembangkan dengan mudah menggunakan plugin dan helper, atau dengan menggunakan hooks.

h. Tidak Memerlukan Template Engine

Meskipun CodeIgniter dilengkapi dengan template parser sederhana yang dapat digunakan, tetapi hal ini tidak mengharuskan kita untuk menggunakannya.

i. Dokumentasi Lengkap dan Jelas

Dari sekian banyak framework, CodeIgniter adalah satu-satunya framework dengan dokumentasi yang lengkap dan jelas.

j. Komunitas

Komunitas CodeIgniter saat ini berkembang pesat. Salah satu komunitasnya bisa dilihat di (http://codeigniter.com/forum/).

Proses aliran data aplikasi pada sistem dapat diilustrasikan seperti terlihat pada gambar 2.2

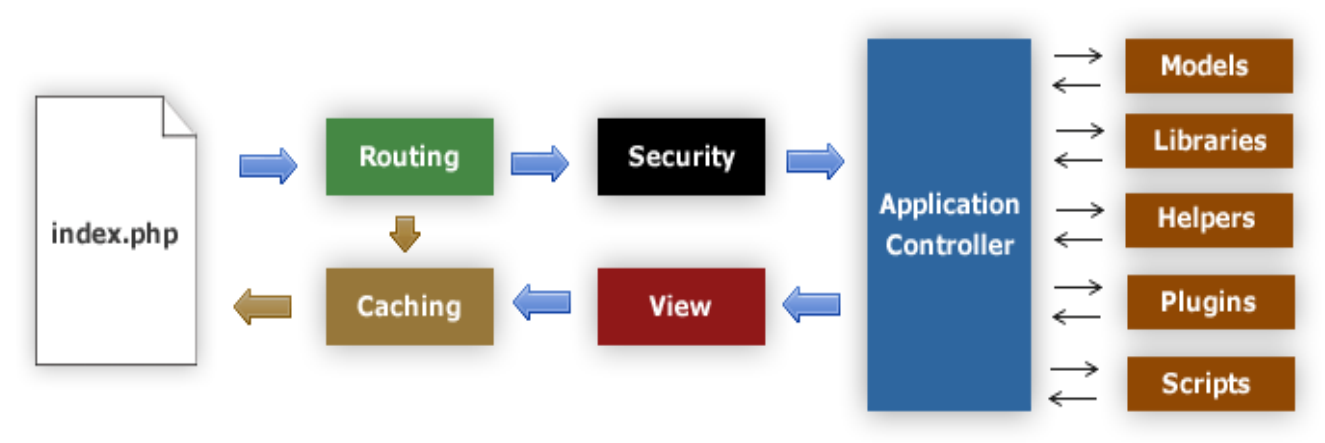

Gambar 2. Application Flowchart

Sumber : Hakim (2010 : 12)

Keterangan :

a. Index.php berfungsi sebagai front controller, menginisialisasi base resorce untuk menjalankan CodeIgniter.

b. Router memerikasa HTTP request untuk menentukan apa yang harus dilakukan dengannya.

c. Jika Cache aktif, maka hasilnya akan langsung dikirimkan ke browser dengan mengabaikan aliran data normal.

d. Security. Sebelum Controller dimuat, HTTP request dan data yang dikirimkan user akan difilter untuk keamanan.

e. Controller memuat model, core libraries, plugins, helpers dan semua resource yang diperlukan untuk memproses request.

f. Akhirnya View yang dihasilkan akan dikirimkan ke browser. Jika Cache aktif, maka View akan disimpan sebagai Cache dahulu, sehingga pada request berikutnya langsung dapat ditampilkan.

2.8. Pengertian MVC (Model-View-Controller)

CodeIgniter adalah framework PHP yang dibuat berdasarkan kaidah modelView-controller. Dengan MVC, maka memungkinkan pemisahan antara layer application-logic dan presentation. Sehingga, dalam sebuah pengembangan web, seorang programmer bisa berkonsentrasi pada core-system, sedangkan web designer bisa berkonsentrasi pada tampilan web. Menariknya, skrip PHP, query MySQL, Javascript dan CSS bisa saling terpisah, tidak dibuat dalam satu 
skrip berukuran besar yang membutuhkan resource besar pula untuk mengesekusinya. Adapun alur program aplikasi berbasis framework Codeigniter dapat dilihat pada gambar 3.

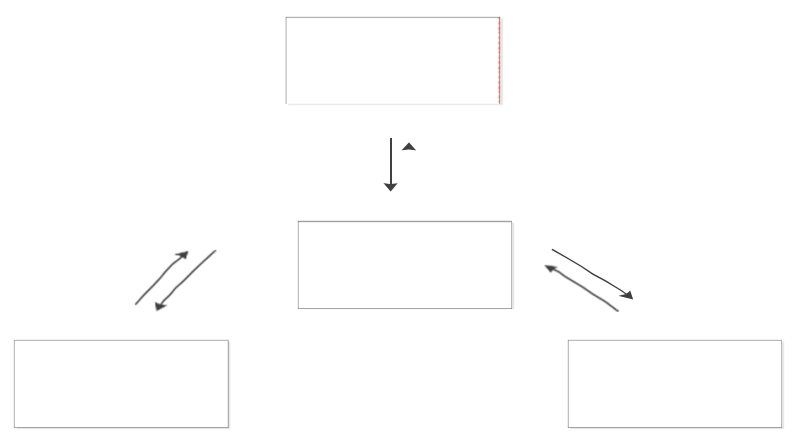

Gambar 3. Model-Viev-Controller

Sumber : Hakim (2010 : 4)

Gambar diatas menerangkan bahwa ketika datang sebuah user request, maka akan ditangani oleh controller, kemudian controller akan memanggil model jika memang diperlukan operasi database. Hasil dari query oleh model kemudian akan dikembalikan ke controller. Selanjutnya controller akan memanggil view yang tepat dan mengkombinasikannya dengan hasil query model. Hasil akhir dari operasi ini akan ditampilkan dibrowser,

Dalam konteks CodeIgniter dan aplikasi berbasis web, maka penerapan konsep MVC mengakibatkan kode program dapat dibagi menjadi tiga kategori, yaitu :

a. Model

Kode program (berupa OOP class) yang digunakan untuk memanipulasi database.

b. View

Berupa template $\mathrm{html} / \mathrm{xml}$ atau php untuk menampilkan data pada browser

c. Controller

Kode program (berupa OOP class) yang digunakan untuk mengontrol aliran aplikasi (sebagai pengontol model dan View)

\subsection{Pengertian Intranet (Internal Network)}

Menurut O'brien (2003:182) intranet adalah suatu jaringan didalam suatu organisasi yang menggunakan internet. Intranet selain digunakan untuk hubungan antar perusahaan, juga digunkan untuk dalam perusahaan itu sendiri, baik dalam satu gedung maupun dengan cabang perusahaan yang berada diluar kota atau diluar negeri.

\subsection{Pengertian Aplikasi Intranet}

Intranet menyediakan portal informasi perusahaan yang menunjang information sharing, communication, collaboration dan dukungan terhadap operasi bisnis dan manajemen. Berikut ini adalah contoh dari pemanfaatan Intranet:

a. Komunikasi dan Kolaborasi Intranet memungkinkan pekerja untuk saling mengirim dan menerima email, voice mail, paging, dan fax.

b. Web Publishing

Intranet membuat promosi suatu perusahaan menjadi lebih menarik dan mempunyai biaya lebih rendah. 


\section{Implementasi}

\subsection{Perancangan}

Berupa tampilan web yang memuat data soal dengan pilihan jawaban, pengguna hanya tinggal memilih jawaban yang dianggap benar sampai selesai, kemudian sistem akan secara otomatis menghitung nilai akhir dan memampilkan hasil tersebut sehingga pengguna dapat melihat langsung hasil dari pelaksanaan Perancangan Prosedur

Berikut adalah prosedur pengoperasian aplikasi :

a. Peserta melakukan proses login dengan cara mengetikkan e-mail dan password dan kemudian menekan tombol 'Login'.

b. Jika Peserta berhasil melakukan proses login, maka aplikasi akan menampilkan halaman dashboard, Peserta menekan menu 'Ujian' untuk memulai ujian.

c. Aplikasi menampilkan soal ujian beserta beberapa pilihan jawaban.

d. Peserta memilih salah satu jawaban pada beberapa soal ujian dan kemudian menekan tombol 'Selesai' untuk berhenti.

e. Peserta selesai mengerjakan ujian.

f. Aplikasi menampilkan nilai hasil ujian Peserta.

\subsection{Diagram Konteks}

Diagram konteks merupakan alat untuk menggambarkan aplikasi secara garis besar atau secara keseluruhan. Pada diagram konteks ini aplikasi yang dibuat akan menghasilkan sumber informasi yang dibutuhkan dan tujuan yang ingin dihasilkan.

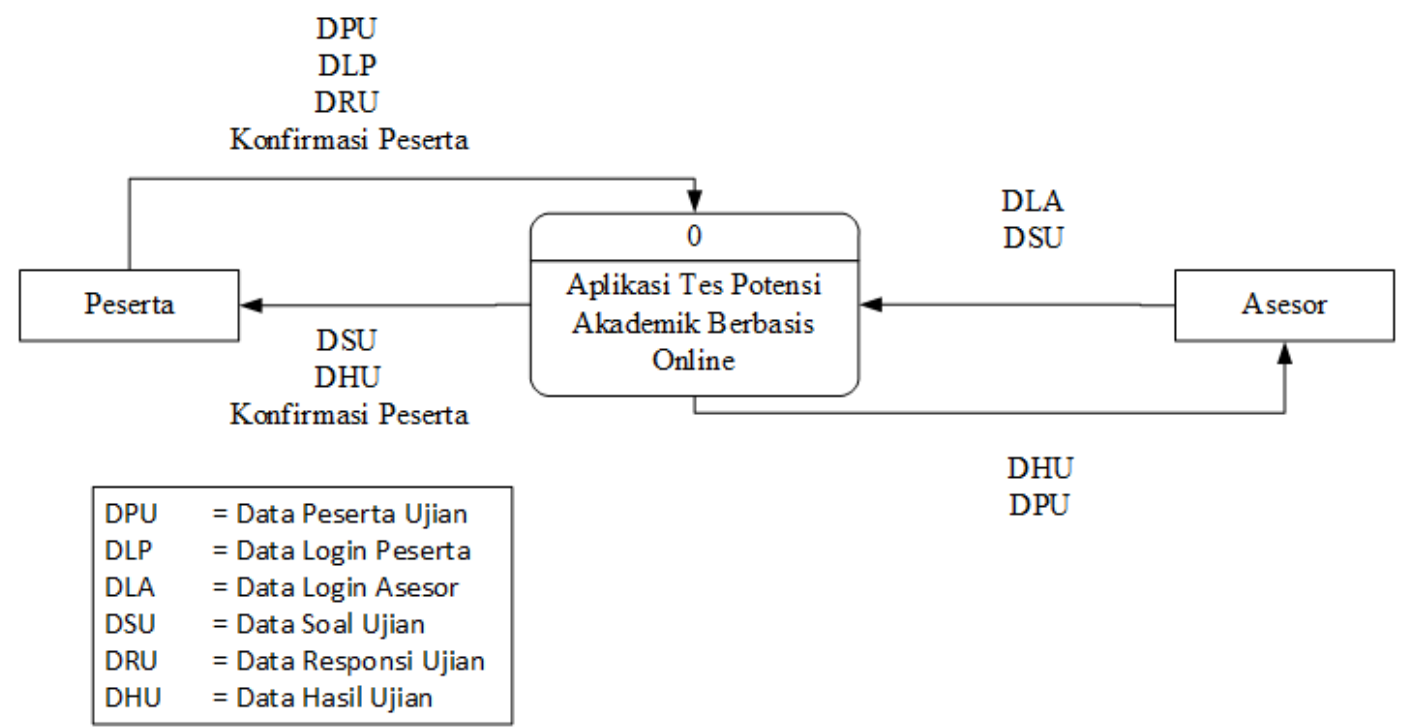

Gambar 4. Diagram Konteks (DAD/DFD Level 0)

\subsection{Diagram Alur Data}

Data Flow Diagram (DFD) adalah suatu gambaran aplikasi secara logika. Diagram biasanya digunakan untuk membuat sebuah modul aplikasi dalam bentuk proses-proses yang saling terhubung satu dengan lainnya sehingga memberikan gambaran yang lebih jelas dan mudah untuk dipahami dalam proses pengolahan data. Dalam gambaran aplikasi ini terbagi menjadi beberapa level diantaranya :

a. Diagram Alur Data/Data Flow Diagram Level 1 


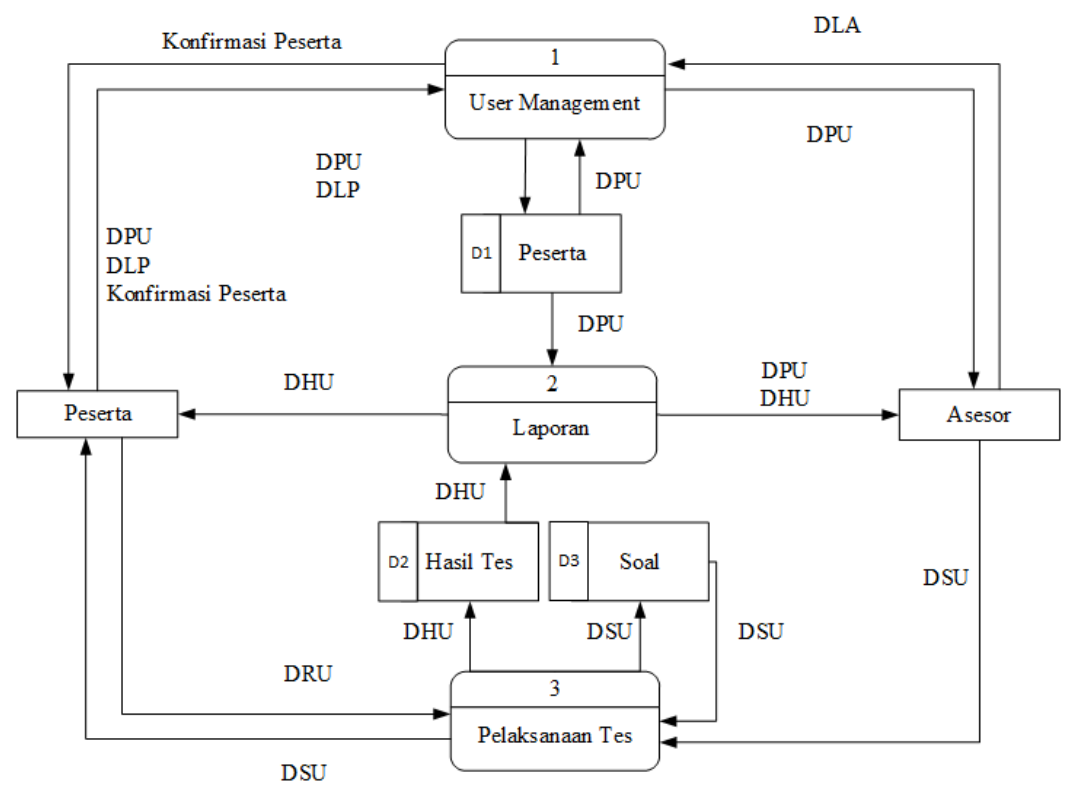

Gambar 5. Diagram Alur Data/Data Flow Diagram Level 1

b. Diagram Alur Data Level 2 (Proses User Management)

Dari DFD level 1 akan diperjelas dengan DFD level 2. Dibawah ini adalah hasil turunan dari Proses 1 (Proses User Management).

Konfirmasi Peserta

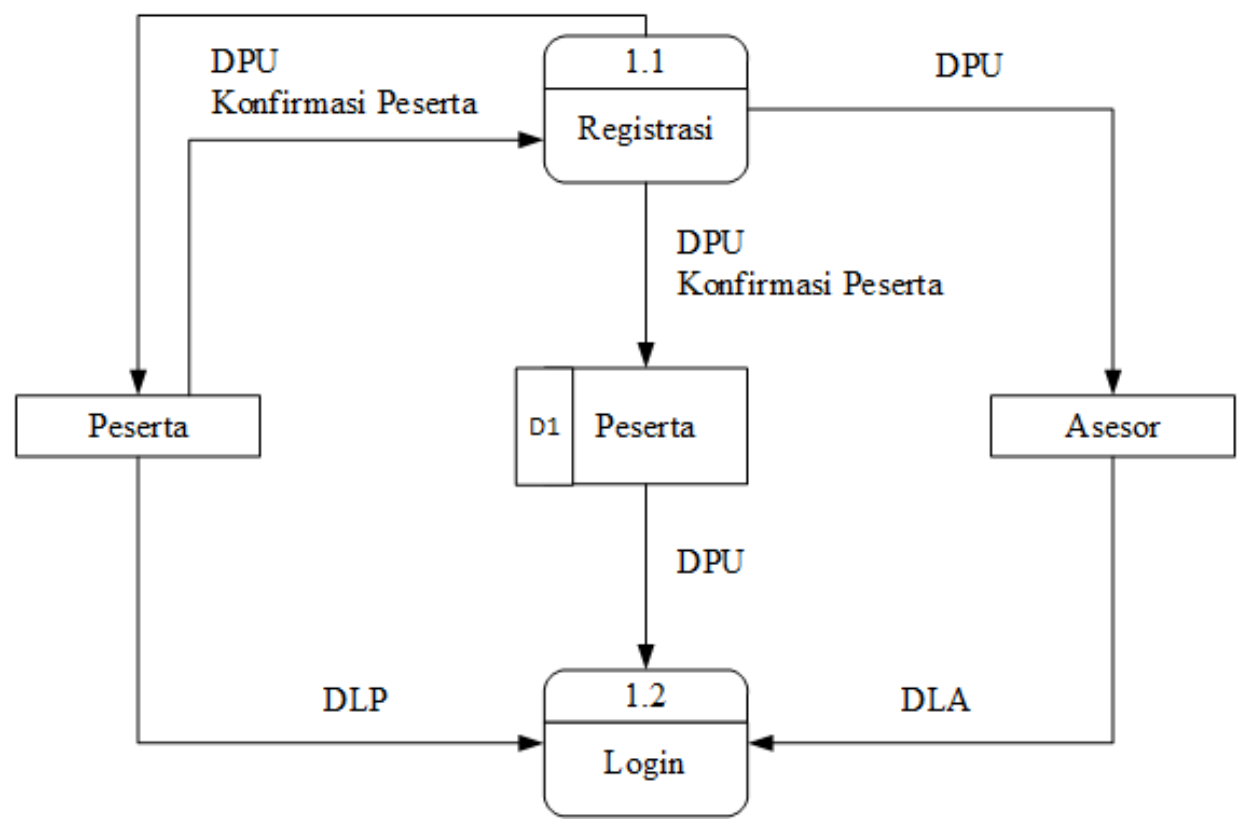

Gambar 6. Diagram Alur Data/Data Flow Diagram Level 2 (User Management)

\subsection{Tabel Relasi}

Tabel Relasi menggambarkan hubungan antar tabel-tabel yang ada pada suatu sistem pengolahan data. 


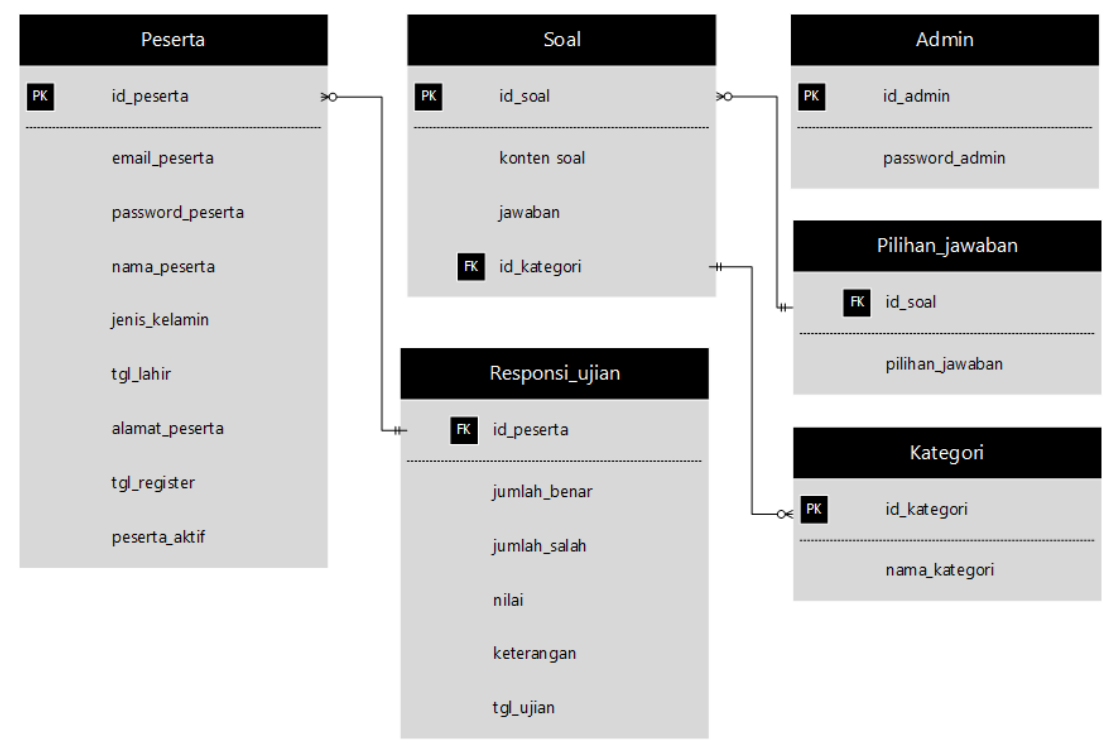

Gambar 7. Tabel Relasi

Entity Relational Diagram adalah suatu model untuk menjelaskan hubungan antar data dalam basis data berdasarkan objek-objek dasar data yang mempunyai hubungan antar relasi.

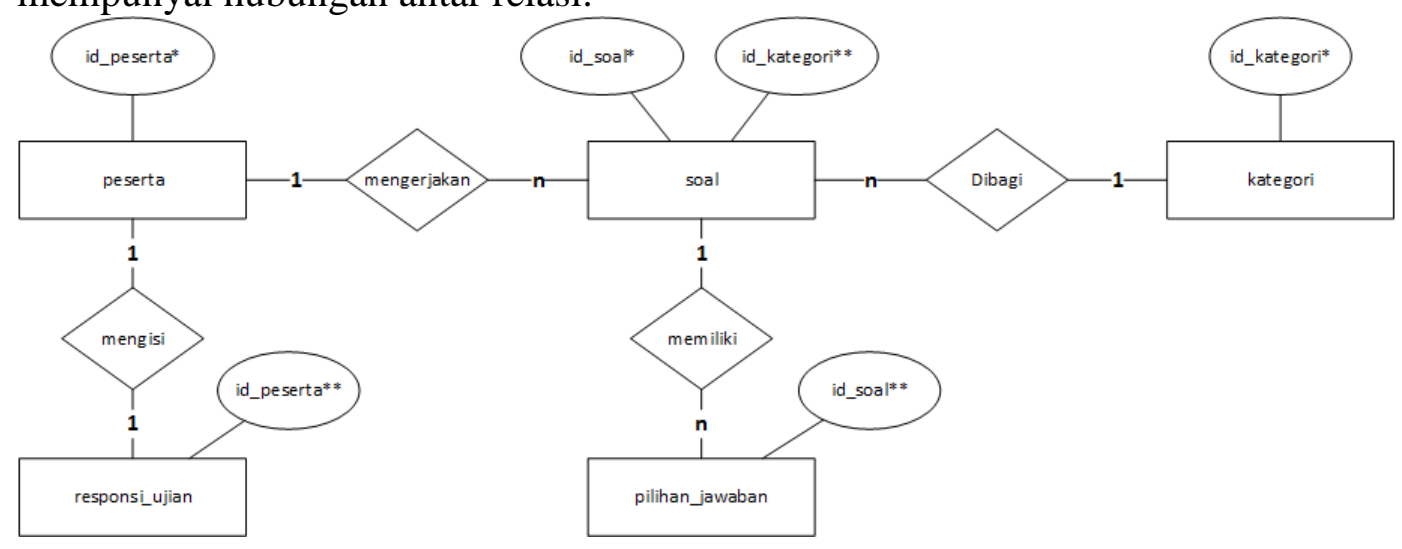

Gambar 8. Entity Relational Diagram

\section{Kesimpulan}

Berdasarkan analisis terhadap masalah yang telah diidentifikasi, maka terdapat beberapa kesimpulan yaitu sebagai berikut:

a. Pada saat ini sistem yang berjalan Potensi Akadmek untuk calon mahasiswa baru masih ditemukan test secara offline diharapkan adanya aplikasi usulan ini akan memudahkan bagian terkait untuk melakukan proses lebih cepat dengan bantuan aplikasi Test potensi akademik seleksi saringan masuk LP3I berbasis web online menggunakan Framework Codeigniter.

b. Proses ujian lebih mudah karena peserta ujian bisa melakukan test dimana saja bahkan bisa melakukan ujian dengan handphone, dan menjadi alat marketing karena mempermudah aplikan atau perserta ujian karena peserta hanya memasukan nomer ujian kemudian peserta ujian dapat langsung mengerjakan secara online. 
c. Aplikasi Test potensi akademik seleksi saringan masuk LP3I berbasis web online menggunakan Framework Codeigniter mempermudah bagian tertentu untuk merekap atau membuat laporan hasil test potensi akademik karena aplikasi ini langsung menampilkan hasil nilainya, bahkan peseta ujian test potensi akademik ini dapat langsung mengetahui nilai hasil mengerjakannya.

\section{Daftar Pustaka}

[1] Sidik, Betha. (2012). Framework CodeIgniter. Bandung: INFORMATIKA.

[2] Basuki, Awan Pribadi. (2010). Membangun Web Berbasis PHP dgn Framework CodeIgniter. Lokomedia

[3] Roviuddin. (2008). WEB PROGRAMMING (HTML, CSS, VBScript dan Jaavascript). Jakarta: Lentera Ilmu Cendekia.

[4] O'Brien, J.A. (2002). Management Information Systems: Managing information technology in the e-business enterprise. 4th ed. New York: McGraw-Hill Inc.

[5] Ladjamudin B, Al-bahra, (2006). Rekayasa Perangkat Lunak. Yogyakarta. Graha Ilmu.

[6] Martina, Inge. (2003). 36 Jam Belajar Komputer Microsoft SQL Server 2000. Jakarta. PT.Elex Media Komputindo

[7] Rosiyadi, Didi. (2007). Analisis dan Desain Sistem Informasi, Bandung, Rosiyadi,

[8] Bodnar, H. George dan William S. Hopwood. (2000). Sistem Informasi Akuntansi, Buku I, Edisi Ke-6, Penerjemah Amir Abadi Jusuf dan Rudi M. Tambunan, Salemba Empat, Jakarta

[9] Taryana Suryana dan Koesheryanti. (2014). Aplikasi Internet Menggunakan HTML.CSS \& Java Script. PT. Elex Media Komputindo. Jakarta

[10] http://getbootstrap.com/

[11] http://www.w3schools.com/

[12] https://ellislab.com/ 